\title{
Pengaruh Budaya Organisasi, Kepuasan Kerja, Komitmen Kerja terhadap Motivasi Guru SD Islam Al Azhar I Pusat
}

\author{
Suwardi \\ Program Studi Pendidikan Anak Usia Dini, Fakultas Psikologi dan Pendidikan, \\ Universitas Al Azhar Indonesia, Jl. Sisingamangaraja, Jakarta 12110 \\ Penulis untuk Korespondensi/E-mail: suwardi@uai.ac.id
}

\begin{abstract}
Abstrak- Dengan menciptakan suasana yang baik terhadap budaya organisasi, kepuasan kerja dan komitmen kerja akan dapat mempengaruhi motivasi kerja guru atau pendidik. Sehingga dengan mengetahui seberapa besar pengaruh budaya organsisasi, kepuasan kerja dan komitmen kerja, maka pihak yang berkepentingan dalam hal ini pemerintah dan pengurus yayasan dapat meninjau kembali aspek mana yang perlu ditingkatkan agar kinerja guru atau pendidik termotivasi secara optimal sesuai dengan tujuan organisasi. Motivasi guru akan berdaya guna dan berhasil guna yang diakibatkan dari pengaruh budaya organisasi, kepuasan kerja dan komitmen kerja. Obyek penelitian adalah guru SD Islam Al Azhar se-Jabodetabek dengan metode penelitian ANAVA. Hasil yang diperoleh dari analisis terdapat pengaruh signifikan budaya organisasi, kepuasan kerja dan komitmen kerja terhadah motivasi kerja guru SD Islam Al Azhar seJabodetabek.
\end{abstract}

Abstract - By creating a good atmosphere of organizational culture, job satisfaction and work commitments will be able to affect the motivation of teachers or educators. So as to determine how much influence, organizational culture, job satisfaction and job commitment, then the interested parties in this case the government and the board of trustees to review the aspects which need to be improved so that the performance of teachers or educators motivated optimally in accordance with the objectives of the organization. Motivation will be empowered teachers and effective as a result of the influence of organizational culture, job satisfaction and job commitment. The research object is the primary teachers of Islam Al Azhar Jabodetabek with research methods ANOVA. The results of the analysis are significant influence organizational culture, job satisfaction and job commitment to the work motivation of Al Azhar Islamic elementary school teacher Jabodetabek. Keywords - Motivasi kerja, Budaya Organisasi,
Komitmen

\section{PENDAHULUAN}

$S$ alah satu tujuan negara dalam UndangUndang Dasar 1945 adalah mencerdaskan kehidupan bangsa dan merupakan juga salah satu tujuan pembangunan sumber daya manusia di Indonesia agar terwujud dari cita-cita bangsa tersebut, disamping itu setiap warga negara Indonesia berhak memperoleh pendidikan yang bermutu sesuai dengan minat dan bakat yang dimilikinya tanpa memandang status sosial, ras, etnis, agama dan gender.

Dengan demikian pemerataan dan mutu pendidikan akan menjadikan warga negara mengenal dan mengatasi masalah diri dan lingkungannya, serta mendorong tegaknya masyarakat madani dan modern yang dijiwai nilai-nilai Pancasila, maka upaya yang ditempuh oleh pemerintah, diantaranya adalah mendorong pertumbuhan lembaga pendidikan baik di sektor pemerintah maupun swasta. Sedangkan pada realitas sosial, dengan semakin banyaknya lembaga pendidikan namun semakin berkurang pula mutu pendidikannya.

Berkenaan dengan hal tersebut, maka Yayasan Pesantren Islam (YPI) Al Azhar berupaya mendirikan pendidikan yang berkualitas dimulai dari Kelompok Bermain, Taman Kanak-Kanak, Sekolah Dasar, Sekolah Menengah Pertama, Sekolah Menengah Atas sampai dengan tingkat perguruan tinggi yakni Universitas Al Azhar 
Indonesia, tujuan berdirinya lembaga pendidikan tersebut ialah menjadi pendidikan yang bernafaskan Islam, sehingga menjadi harapan bangsa dan umat, selain dari pada itu menjadikan suatu center of excellence. Dalam hal ini makna center of excellence dalam kaidah Bahasa Indonesia sebagai pusat keunggulan atau memiliki makna sebagai institusi penggerak utama untuk mencapai keunggulan. Jika sebuah institusi pendidikan ingin menjadi center of excellence, maka institusi itu mengemban tugas untuk berkontribusi menghasilkan sumber daya manusia yang bermartabat dan unggul diberbagai organisasi, sehingga dapat mendorong menjadi organisasi berkinerja tinggi (high performance organization), maka dalam hal ini diperlukan pendidik atau guru yang memiliki dedikasi yang tinggi terhadap lembaga pendidikan tersebut.

\section{Permasalahan}

Berdasarkan latar belakang yang telah diuraikan di atas, maka rumusan masalahnya adalah (1) Apakah terdapat pengaruh budaya organisasi terhadap motivasi kerja guru ?, (2) Apakah terdapat pengaruh kepuasan kerja terhadap motivasi kerja guru?, (3) Apakah terdapat pengaruh komitmen kerja terhadap motivasi kerja guru ?, dan (4) Apakah terdapat pengaruh budaya organisasi, kepuasan kerja, komitmen kerja secara bersamasama terhadap motivasi kerja guru ?

\section{Tujuan Program}

Tujuan Khusus dan urgensi penelitian ini adalah untuk memperoleh informasi empirik tentang pengaruh budaya organisasi, kepuasan kerja, komitmen kerja secara bersama- sama terhadap motivasi kerja guru. Adapun manfaat Penelitian ini berikut adalah sebagai berikut: Bagi Pengurus Yayasan Pesantren Islam (YPI) Al Azhar, sebagai bahan masukan untuk membuat kebijakan dalam mengelola sumber daya pendidikan secara professional sesuai dengan visi dan misinya, sehingga mampu meningkatkan mutu pendidikan bagi lembaga dan organisasi pendidikan lainnya, sebagai contoh kongkrit dalam mengelola manajemen yang sesuai dengan organisasinya, sedangkan bagi peneliti lainnya, sebagai bahan tambahan referensi pengetahuan bagi penulis dan pemerhati SDM terutama yang berkaitan dengan budaya organisasi, kepuasan kerja, komitmen kerja terhadap motivasi kerja.

\section{KAJIAN TEORITIS}

\section{Motivasi Kerja}

Istilah motivasi berasal dari bahasa Latin yaitu "movere" yang berarti to move (dorongan) [1]. Sedangkan Robbins mengatakan motivasi adalah keinginan untuk melakukan sesuatu dan dikondisikan oleh kemampuan seseorang untuk bertindak dalam memenuhi sebagian kebutuhan [2]. Dari pendapat para ahli ini dapat disimpulkan motivasi adalah (1) dorongan yang ditimbulkan dari diri seseorang, sadar atau tidak sadar untuk melakukan suatu tindakan dengan tujuan tertentu, atau (2) usaha yang menyebabkan seseorang atau sekelompok orang tergerak untuk melakukan sesuatu karena ingin mencapai tujuan yang dikehendaki atau mendapatkan kepuasan dengan perbuatannya itu.

Irawan menyebutkan bahwa dalam teori hierarki kebutuhan Maslow bahwa seseorang termotivasi oleh hasrat untuk memenuhi kebutuhannya yang terbagi atas : (1) kebutuhan dasar (physiological needs), (2) kebutuhan rasa aman (security and safety needs), (3) kebutuhan sosial (belonging and affection needs), termasuk berhubungan dengan orang lain, memberi dan menerima cinta, menyayangi dan kerjasama, (4) kebutuhan prestise (esteem needs), termasuk keinginan untuk dihargai, mandiri, dipertimbangkan dan dihormati orang lain, (5) kebutuhan aktualisasi diri (self-actualization), termasuk keinginan untuk tumbuh, berkembang, merealisasikan potensi [3].

Terdapat hubungan di dalam suatu keberhasilan suatu pekerjaan, diantaranya motivasi untuk membentuk suatu kepuasan dengan satu unit kelompok kecil maupun kelompok kerja [4]. Motivasi bersama dalam kerja guru atau antara guru dengan murid, dan antara guru dengan masyarakat akan membawakan keberhasilan kerja. Hubungan dalam unit kerja sulit dicapai secara sempurna terutama pada bidang sekolah/akademik. Hubungan antara guru, murid, kepala sekolah dan masyarakat memberikan suatu motivasi keberhasilan pengelola sekolah diantaranya guru.

Teori yang mengarah pada prestasi dan produktivitas dalam konsepsinya mengenai motivasi dalam diri individu terdapat tiga motivasi yang mendorong tingkah lakunya meliputi, pertama, kebutuhan akan prestasi (need achievement), yaitu dorongan untuk mengungguli 
berprestasi sehubungan dengan seperangkat standar, dan berjuang untuk sukses[5].

Kedua, kebutuhan kekuasaan (need power), yaitu kebutuhan untuk membuat orang-orang lain berperilaku dalam suatu cara yang orang-orang itu tanpa paksaan tidak berlaku demikian. Ketiga adalah kebutuhan untuk berhubungan dengan orang lain (need affiliate), yaitu kebutuhan untuk bersosialisasi dengan orang lain, sebagai manusia membutuhan hubungan ini untuk seluruh aktivitasnya baik yang bersifat pekerjaan maupun bersifat psikologis.

Berdasarkan dari beberapa teori di atas maka dapat diketahui bahwa motivasi kerja berkaitan erat dengan pemenuhan kebutuhan, sehingga teori-teori mengenai pemenuhan kebutuhan seperti Maslow, McCelland, ERG oleh Alderfer, dan lain-lain dapat digunakan untuk menunjang dalam menggali teori motivasi kerja.

Berdasarkan uraian di atas maka dapat dinyatakan pengertian motivasi kerja dalam penelitian ini adalah keinginan atau dorongan dari dalam diri seseorang untuk melaksanakan tugas atau pekerjaannya dengan mencapai hasil terbaik, yang diperoleh dari skor jawaban responden terhadap instrumen yang mengukur indikator-indikator: kebutuhan dasar, kebutuhan rasa aman, kebutuhan sosial, kebutuhan prestise, kebutuhan aktualisasi diri.

\section{Budaya Organisasi}

Dalam setiap organisasi baik itu perusahaan maupun pendidikan di dalamnya terdapat suatu budaya. Budaya tersebut sangat berpengaruh pada kegiatan yang ada di dalamnya, karena budaya kerja merupakan suatu tatanan menyelenggarakan tugas fungsi yang diemban, nilai-nilai yang dianut yang dapat membuat orang-orang yang berada di dalamnya merasa memiliki loyalitas, dalam hal ini tanggung jawab untuk mencapai tujuan organisasi.

Budaya organisasi berkaitan dengan nilai yang dianut oleh suatu organisasi. Nilai tersebut menginspirasi setiap individu untuk menentukan tindakan dan perilaku yang dapat diterima oleh organisasinya untuk mencapai tujuan organisasi. Nilai yang membentuk budaya organisasi seringkali tidak diterima begitu saja, tidak tertulis, tetapi merupakan hasil suatu usaha kompromi bersama para individu organisasi. Untuk mentransfer nilai- nilai budaya digunakan atribut sebagai bahasa komunikasi. Atribut yang digunakan organisasi mengandung pesan yang dapat dipahami oleh seluruh anggota organisasi.

Budaya organisasi adalah kumpulan asumsi-asumsi, keyakinan-keyakinan, nilai-nilai, norma-norma yang dianut bersama oleh seluruh anggota organisasi. Sedangkan menurut Yukl, budaya organisasi adalah asumsi-asumsi, keyakinankeyakinan dasar yang dianut bersama oleh seluruh anggota organisasi [6]. Robbins mengemukakan budaya organisasi adalah suatu persepsi bersama yang dianut oleh seluruh anggota organisasi, suatu sistem makna bersama[7].

\section{Karakteristik Budaya Organisasi}

Karakteristik budaya organisasi dalam suatu perusahaan sangat berguna untuk menilai perguruan tinggi dan menjadi dasar untuk perasaan pemahaman bersama yang dimiliki para karyawan mengenai perguruan tinggi, bagaimana urusan diselesaikan, cara para karyawan diharapkan berperilaku dan untuk menciptakan budaya yang berbeda dengan perguruan tinggi lain.

Menurut Robbins, karakteristik yang membentuk budaya organisasi dibagi dalam 7 (tujuh) kelompok [7]. Pertama, Inovasi dan pengambilan resiko, artinya setiap karyawan akan memberikan perhatian yang lebih terhadap setiap permasalahan yang dapat membuat resiko kerugian dalam organisasi secara keseluruhan. Kedua, perhatian terhadap detail, artinya setiap karyawan memberikan perhatian secara detail dalam melakukan pekerjaan. Ketiga, orientasi terhadap hasil, artinya pihak manajemen mengarahkan dan memberdayakan visi perusahaan terhadap karyawan dengan baik, dimana dalam visi tersebut terdapat tujuan organisasi. Keempat, orientasi terhadap individu, artinya pihak manajemen lebih memperhatikan hasil dari masingmasing individu dalam setiap melakukan pekerjaan. Kelima, orientasi terhadap tim, artinya keberhasilan suatu organisasi salah satunya ditentukan oleh kekompakan tim dan atasan yang dapat menyampaikan visinya dengan baik. Keenam, agresivitas, artinya setiap karyawan harus memiliki keahlian, kedisiplinan, dan kerajinan yang baik dalam melaksanakan pekerjaannya dan ketujuh adalah stabilitas, artinya setiap karyawan harus memiliki kondisi yang baik dan prima dalam melakukan pekerjaannya. 


\section{Kepuasan Kerja}

Pengertian kepuasan kerja menurut Robbins dan Judge dikatakan bahwa suatu perasaan positif tentang pekerjaan seseorang yang merupakan hasil evaluasi karakteristik (Job satisfiction as a positive feeling about one's job resulting from an evaluation of its caracteristics). Sedangkan dalam model kepuasan kerja dijelaskan secara teoritik yang dikemukaan oleh beberapa ahli [5].

Pemenuhan kebutuhan (need fulfillment) menurut Mc Clelland dalam Robbins berkenaan dengan kepuasan kerja menyatakan bahwa dalam individu terdapat tiga kebutuhan hidup yang mendorong tingkah lakunya yaitu : a) kebutuhan akan prestasi (need for achievement),b) kebutuhan untuk berhubungan dengan orang lain (need for affiliation), c) kebutuhan kekuasaan (need for power) [5].

Pandangan Kreitner dan Kinicki dalam Robbins mengenai kepuasan kerja yaitu adanya perbedaan, harapan yang terpenuhi mewakili perbedaan antara apa yang diharapkan oleh seorang invidu dari sebuah pekerjaan dengan apa yang kenyataan diterimanya[5]. Model ini memprediksi bahwa individu akan puas jika kenyataan yang diterima melampaui harapannya. Masih dalam pandangan Kreitner dan Kinicki menyatakan yang melandasi nilai adalah kepuasan yang berasal dari persepsi bahwa suatu pekerjaan memungkinkan untuk memenuhi nilai-nilai kerja yang penting dari seorang individu. Oleh karenanya para guru dapat meningkatkan kepuasan melalui strukturisasi lingkungan kerja, penghargaan dan pengakuan yang berhubungan dengan nilai-nilai. Pada dasarnya kepuasan kerja tergantung kepada kesesuain antara nilai keluaran yang dipetroleh antara individu pada pekerjaannya atas persepsi mengenai kemampuan hasil tersebut. Keadilan juga factor yang berpengaruh pada kepuasan kerja.

Suatu fungsi dari model ini adalah bagaimana seorang individu diperlakukan secara adil di tempat kerja. Kepuasan dari persepsi seseorang bahwa output pekerjaan relatif sama dengan inputnya, perbandingan yang mendukung output atau input lain signifikan. Kepuasan kerja berkaiatan dengan rasa keadilan yaitu suatu fungsi yang menggambarkan sejauh mana kewajaran yang diterima oleh seseorang dalam melaksanakan suatu pekerjaan. Watson dalam Equity Theory menjelaskan bahwa kepuasan kerja merupakan hasil persepsi dari keadilan berkenaan denan input dan outcome.

Sedangkan teori keadilan yang dikemukakan Adams dalam Allens bahwa kepuasan kerja adalah penilian individu terhadap keadilan yang diterimanya, karena beranggapan bahwa seseorang merasa puas jika ratio input-outcomes yang diperolehnya dibandingkan input-outcomes orang lain dirasa cukup adil [8]. Jadi kepuasaan adalah konsekuensi, ketika apa yang guru harapkan terpenuhi dan ini akan menjadi motivasi untuk sesuatu ke depan. Kepuasan kerja pada prinsipnya adalah sikap atau perasaan seseorang terhadap pekerjaannya yang dapat dilihat dari keyakinan, perasaan dan perilakunya terhadap semua aspek yang terkait dengan pekerjaannya sebagai guru [8].

\section{Komitmen Kerja}

Bobbi dan Mike menyebutkan bahwa komitmen adalah tekad yang kuat, yang mendorong untuk mewujud-kannya, terlepas dari beberapa rintangan yang mungkin dihadapi [9]. Sedangkan, Stout dan Walker mengemukakan komitmen adalah menemukan suatu tujuan khusus yang diinginkan sehingga seseorang mau memberikan mutu, energi, dan kemampuan untuk membantu mendapatkannya [10]. Selanjutnya, Walker (1992:87) mendefenisikan" Commitment is the willingness of people to stay with the organization and contribute energeticaly to achievement of share objective".Pendapat yang sama juga mengatakan "commitment is critical to organizational performance, but it is a panacea." Dari pernyataan tersebut dapat dijelaskan bahwa (1) seseorang yang memiliki komitmen akan melakukan pekerjaan dengan mengacu pada kemampuan yang optimal, (2) dalam melakukan pekerjaan seseorang akan memberikan kontribusi dengan memperhatikan kualitas atau mutu pekerjaan, (3) bekerja dengan sungguh-sungguh, bersemangat, dan menjalin kerjasama yang baik agar tercapai tujuan organisasi serta memiliki keberhasilan terhadap organisasi [11].

Dimensi-dimensi komitmen kerja sebagai kriteria, sekaligus memperhatikan derajat komitmen seseorang pada pekerjaannya yang meliputi: (1) kemampuan mengetahui (knowledgeability), (2) kegiatan terarah mengimplementasikan keputusan awal tentang pekerjaan yang dipilih (activity drected toward implementing the chosen identity elements),(3) keterlibatan emosional berkaitan komitmennya (emotional tone), (4) upaya 
mengidentifikasi diri terhadap orang-orang yang menjadi teladan dibidangnya (identification with significant others), (5) memproyeksikan masa depan yang jelas (projecting one's personal future), (6) bertahan dengan pekerjaan yang dipilih (resistence to being swayed). Dengan demikian dipandang sudut derajat artikulasi makna komitmen adalah interaksi antara berbagai aktifitas manusia yang mempertahankan dan menyelenggarakan hidupnya dengan mengkolaborasikan semua dimensi komitmen pilihan. Relevansi pilihan dalam menyelenggarakan hidup sehari-hari amatlah tergantung kepada motivasi seorang guru yang profesional.

Kemudian Mowdey, Porter dan Steers mendefinisikan "Commitment is the relative streght of an individual's identification with and involvement in a particular organization" , komitmen di atas bercirikan adanya : (1) belief yang kuat serta penerimaan terhadap tujuan dan nilai organisasi, (2) kesiapan untuk bekerja keras serta (3) keinginan yang kuat untuk bertahan dalam organisasi [2]. Berkaitan dengan sejauh mana individu merasa nilai dan tujuan pribadinya sesuai dengan nilai dan tujuan organisasi, maka komitmen tersebut tergolong komitmen sikap atau afektif. Steers and Porter menyatakan ada tiga tahap dalam pembentukan komitmen yaitu pertama, compliance, tahap dimana seseorang menerima sebagian besar pengaruh untuk mendapatkan sesuatu dari orang lain misalnya pembayaran, kedua identification, tahap individu menerima pengaruh yang dapat menimbulkan hal yang menyenangkan dan membangun hubungan, saat ini orang akan merasa bangga menjadi bagian dari organisasi, dan ketiga internalization, tahap dimana individu menemukan nilai - nilai organisasi yang secara intrinsik menguntungkan dan berharga bagi nilai-nilai individu [1].

Sedangkan Allen dan Meyer mengemukakan bahwa tipologi komitmen organisasi atas tiga komponen yaitu: komitmen afektif (affective commitment), komitmen berkesimbungan (continuance commitment), dan komitmen normatif (normative commitment). Hal yang umum dari ketiga komponen komitmen ini adalah dilihatnya komitmen sebagai kondisi psikologis yang:(1) menggambarkan hubungan individu dengan organisasi, dan (2) mempunyai implikasi dalam keputusan utuk meneruskan atau tidak keanggotaannya dalam organisasi [8].
Dari definisi dan tipologi komitmen yang dikemukakan oleh para ahli di atas dapat memperjelas arah dan pemahaman tentang komponen-komponen komitmen organisasi sebagai berikut : Komitmen afektif yang berkaitan dengan keterlibatan emosional karyawan, identifikasi karyawan pada organisasi dan keterlibatan karyawan pada organisasi; Komitmen berkesinambungan berkaitan dengan keinginan untuk tetap bekerja atau justru meninggalkan organisasi; Komitmen normatif berkenaan dengan perasaan wajib utuk tetap bekerja dalam organisasi.

Dengan demikian komitmen kerja adalah pendapat seseorang mengenai loyalitas, keberpihakan dan keterlibatan dalam organisasi, termasuk kesetiaan pada organisasi dan kesediaan untuk tetap menjadi bagian organisasi, mematuhi peraturan organisasi, berperan aktif dalam kegiatan dan bertanggung jawab terhadap organisasi.

Secara konseptual terdapat tiga faktor yang mempengaruhi komitmen: 1) suatu keyakinan yang kuat dan menerima tujuan-tujuan serta nilai-nilai organisasi, 2) kemauan untuk melaksanakan upaya untuk kepentingan organisasi 3) adanya suatu keinginan yang kuat untk memelihara keanggotaan dalam organisasi [12].

Sementara Panji menyebutkan pengertian kerja dapat dijelaskan: 1) kerja merupakan bagian yang paling mendasar bagi hidup manusia, karena dia memberikan status kepada masyarakat, juga bisa mengikat individu lain baik yang bekerja atau tidak ,2) baik pria atau wanita menyukai pekerjaan karena faktor sosial dan psikologis dari pekerjaan itu, 3) moral dari pekerjaan itu mempunyai hubungan langsung dengan kondisi materi yang menyangkut pekerjaan itu, dan 4) insentif dari kerja tersebut banyak bentuk, tidak semata dalam bentuk uang [13].

Berdasarkan pernyataan tersebut dapat dinyatakan kerja diartikan sebagai suatu kondisi yang dibutuhkan manusia. Seorang bekerja karena ingin memenuhi kebutuhannya sehingga melalui aktivitas kerja yang dilakukannya akan membawanya kepada suatu keadaan yang lebih baik, karena kebutuhannya terpenuhi. Dengan bekerja seseorang tidak semata mendapatkan penghasilan, tetapi banyak lagi aspek lainnya yang dapat dicapai dari pekerjaannya, seperti status sosial, penghargan dan lain-lain. 
Berdasarkan uraian di atas, yang dimaksud dengan Komitmen Kerja guru adalah keberpihakan seseorang guru secara psikologis terhadap pekerjaannya untuk mencapai tujuan, yang diperoleh dari hasil penilaian dalam bentuk skor setelah diberikan alat ukur yang didefinisikan oleh indikator-indikator: mengenai loyalitas, keberpihakan dan keterlibatan dalam sekolah, termasuk kesetiaan pada sekolah dan kesediaan untuk tetap menjadi bagian sekolah, mematuhi peraturan sekolah, berperan aktif dalam kegiatan dan bertanggung jawab terhadap pekerjaan.

\section{METODE PENELITIAN}

\section{Tempat dan Waktu Penelitian}

Penelitian ini dilakukan pada SD Islam Al Azhar I Pusat, adapun waktu penelitian dilaksanakan pada bulan Pebruari 2013 sampai dengan Mei 2013. Dalam kurun waktu semester tahun pertama digunakan untuk mengurus izin penelitian, uji coba instrumen, kalibrasi dan penyempurnaan instrument dan semester tahun terakhir digunakan untuk mengumpulkan data, analisis data dan penulisan seminar hasil dan pelaporan.

\section{Desain Penelitian}

Penelitian dengan menggunakan metode survey dengan pendekatan kausal. Dalam penelitian kausal digunakan teknis analisis data analisis jalur (path analysis). Penelitian ini akan mengkaji atau menganalisis keterkaitan antar variabel penelitian, serta mengukur pengaruh satu variabel terhadap variabel lainnya.

\section{Populasi, dan Sampling}

Populasi target dalam penelitian ini adalah guru-guru SD Islam Al Azhar I Pusat. Populasi terjangkau dalam penelitian ini adalah 60 guru, sedangkan teknik pengambilan sampel yang digunakan simple random. Sampling yaitu penarikan sampel yang dilakukan secara acak sederhana. Dengan menggunakan teknik ini memperoleh 30 sampel dari populasi terjangkau sebanyak 60 guru.

\section{Teknik Pengumpulan Data}

Teknik pengumpulan data dilakukan dengan menggunakan kuesioner kepada responden yang terdiri dari para guru. Penilaian dilakukan dengan menggunakan skala penilaian (rating scale), untuk menilai guru SD Islam Al Azhar I Pusat yang dijadikan sampel dalam penelitian ini.
Kuesioner Kepada responden digunakan untuk memperoleh data mengenai budaya organisasi, kepuasan kerja, komitmen kerja dan motivasi kerja.

Agar dalam pembahasan lebih terarah dan mudah dipahami, aspek yang diteliti, yaitu budaya organisasi yaitu inovasi dan pengambilan resiko, perhatian terhadap detail, orientasi terhadap hasil, orientasi terhadap individu, orientasi terhadap tim; kepuasan kerja yaitu pemenuhan kebutuhan, perbedaan, nilai yang dicapai, keadilan; komitmen kerja yaitu loyalitas pada organisasi, keberpihakan pada organisasi, keterlibatan organisasi; dan motivasi Kerja, yaitu kebutuhan dasar, kebutuhan rasa aman, kebutuhan sosial, kebutuhan prestise, kebutuhan aktualisasi diri.

\section{HASIL DAN PEMBAHASAN}

\section{Uji Normalitas}

Berdasarkan perhitungan uji normalitas dengan menggunakan SPSS diperoleh nilai signifikansi pada tabel 1 bahwa $\rho>0,05$ maka dapat kita simpulkan bahwa data Motivasi Kerja (Y), Budaya Organisasi $\left(\mathrm{X}_{1}\right)$, Kepuasan Kerja $\left(\mathrm{X}_{2}\right)$ dan Komitmen Kerja $\left(\mathrm{X}_{3}\right)$ adalah berdistribusi normal.

Tabel 1. Hasil Uji Normalitas Variabel $\mathrm{X}_{1}, \mathrm{X}_{2}, \mathrm{X}_{3}$ dan $\mathrm{Y}$

Tests of Normality

\begin{tabular}{lrrrrrrr}
\hline & \multicolumn{3}{c}{ Kolmogorov-Smirnov $^{\text {a }}$} & \multicolumn{3}{c}{ Shapiro-Wilk } \\
\cline { 2 - 7 } & Statistic & df & Sig. & Statistic & df & Sig. \\
\hline $\mathrm{Y}$ &, 154 & 17 &, $200^{*}$ &, 975 & 17 &, 903 \\
$\mathrm{X}_{1}$ &, 182 & 17 &, 138 &, 946 & 17 &, 398 \\
$\mathrm{X}_{2}$ &, 142 & 17 &, $200^{*}$ &, 961 & 17 &, 642 \\
$\mathrm{X}_{3}$ &, 192 & 17 &, 094 &, 891 & 17 &, 048 \\
\hline
\end{tabular}

*. This is a lower bound of the true significance.

a. Lilliefors Significance Correction

\section{Deskripsi Hasil Penelitian}

Dalam rangka memaparkan beberapa statistik deskriptif variabel-variabel yang diukur atau diamati dalam penelitian digunakan deskripsi data penelitian. Beberapa statistika deskripstif yang disajikan pada bagian ini meliputi : nilai rata-rata hitung, modus, median. Adapun variabel-variabel yang diukur atau diamati dalam penelitian ini, dibedakan menjadi dua kelompok, yaitu : variabel 
endogen dan variabel eksogen. Variabel endogen adalah variabel yang nilai-nilainya ditentukan di dalam sistem yang diteliti sesuai dengan model teori dalam penelitian. Variabel endogen dalam penelitian ini adalah kinerja guru (X). Selanjutnya, variabel eksogen adalah variabel-variabel yang nilai-nilainya tidak ditentukan di dalam sistem, tetapi di luar sistem yang diteliti. Variabel-variabel eksogen ini menentukan nilai variabel endogen (kinerja guru). Variabel eksogen dalam penelitian ini meliputi : budaya organisasi, kepuasan kerja dan komitmen kerja.

Responden sementara yang dapat diteliti berjumlah 17 responden dari 30 responden. Responden yang diteliti untuk mengisi kuisioner adalah guru-guru di SD Islam Al Azhar Pusat. Rincian jumlah instrumen yang digunakan adalah sebagai berikut : Instrumen Motivasi Kerja Guru sebanyak 33 butir valid, Instrumen Budaya Organisasi 37 butir valid, Instrumen Kepuasan Kerja sebanyak 32 butir valid, dan instrumen Komitmen Kerja sebanyak 31 butir valid. Namun untuk mempermudah dalam menganalisis maka digunakan 30 butir yang valid dari masing-masing instrumen. Data deskripsi penelitian dapat dilihat pada Tabel 2 .

Tabel 2. Deskripsi Data Penelitian Statistics

\begin{tabular}{lrrrr}
\hline & \multicolumn{1}{c}{$\mathrm{X}_{1}$} & \multicolumn{1}{c}{$\mathrm{X}_{2}$} & \multicolumn{1}{c}{$\mathrm{X}_{3}$} \\
\hline $\mathrm{N} \quad$ Valid & 17 & 17 & 17 & 17 \\
$\quad$ Missing & 0 & 0 & 0 & 0 \\
Mean & 113 & 114,88 & 95,18 & 108,94 \\
Median & 110 & 114 & 95 & 106 \\
Mode & 110 & 107 & $92^{\mathrm{a}}$ & 104 \\
Std. Deviation & 9,480 & 7,960 & 6,729 & 7,344 \\
Range & 39 & 27 & 27 & 22 \\
Minimum & 94 & 102 & 82 & 99 \\
Maximum & 133 & 129 & 109 & 121 \\
\hline
\end{tabular}

a. Multiple modes exist. The smallest value is shown

\section{Motivasi Kerja Guru (Y)}

Dari data deskripsi skor dapat kita lihat bahwa dari 30 butir valid yang dianalisis, rentangan skor teoritik antara 94 sampai dengan 133. Data penelitian selanjutnya nilai rata-rata sebesar 133 dengan modus 110 dan median 110. Standar deviasi sebesar 9,48. Selanjutnya secara visual skor Motivasi Kerja digunakan histogram pada Gambar 1.

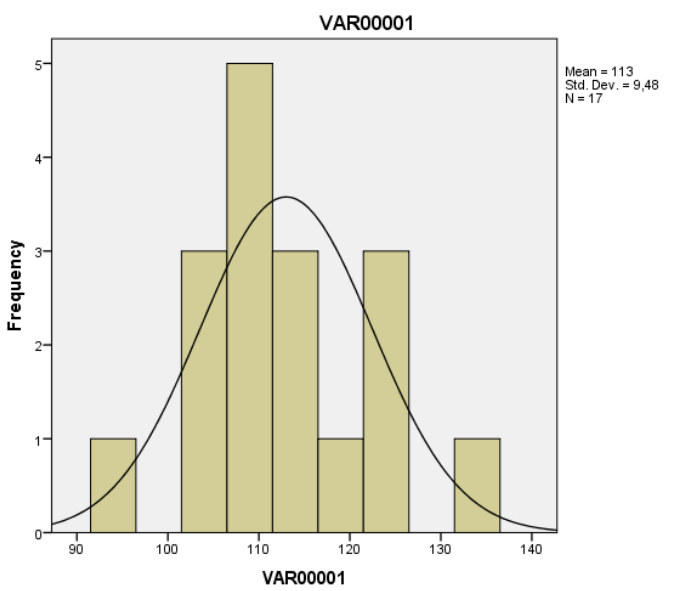

Gambar 1. Histogram Skor Variabel Motivasi Kerja

\section{Budaya Organisasi $\left(X_{I}\right)$}

Dari data deskripsi skor dapat kita lihat bahwa dari 30 butir valid yang dianalisis, rentangan skor teoritik antara 102 sampai dengan 129. Data penelitian selanjutnya nilai rata-rata sebesar 114,88 dengan modus 107 dan median 114. Standar deviasi sebesar 7,96. Selanjutnya secara visual skor Budaya Organisasi $\left(\mathrm{X}_{1}\right)$ digunakan histogram sebagai berikut pada gambar 2 .

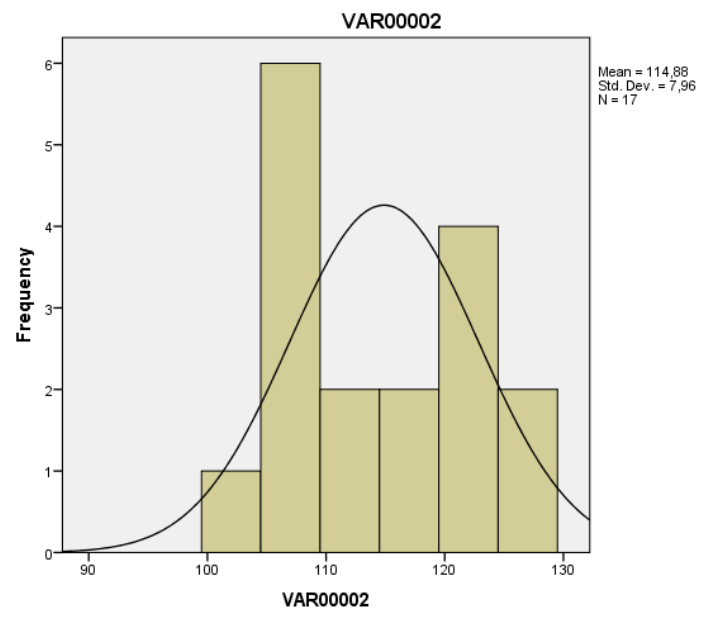

Gambar 2. Histogram Skor Variabel Budaya Organisasi

\section{Kepuasan Kerja $\left(\mathbf{X}_{2}\right)$}

Dari data deskripsi skor dapat kita lihat bahwa dari 30 butir valid yang dianalisis, rentangan skor teoritik antara 82 sampai dengan 109. Data penelitian selanjutnya nilai rata-rata sebesar 95,18 dengan modus 92 dan median 95. Standar deviasi 
sebesar 6,729. Selanjutnya secara visual skor Kepuasan Kerja $\left(\mathrm{X}_{1}\right)$ digunakan histogram sebagai berikut pada gambar 3 .

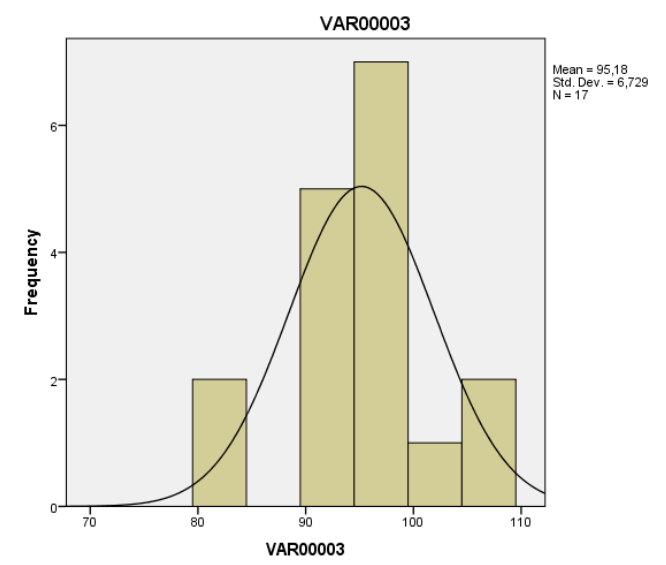

Gambar 3. Histogram Skor Variabel Kepuasan Kerja

\section{Komitmen Kerja $\left(\mathbf{X}_{\mathbf{3}}\right)$}

Dari data deskripsi skor dapat kita lihat bahwa dari 30 butir valid yang dianalisis, rentangan skor teoritik antara 99 sampai dengan 121. Data penelitian selanjutnya nilai rata-rata sebesar 108,94 dengan modus 104 dan median 106. Standar deviasi sebesar 7,344. Selanjutnya secara visual skor Komitmen Kerja $\left(\mathrm{X}_{3}\right)$ digunakan histogram sebagai berikut pada gambar 4 .

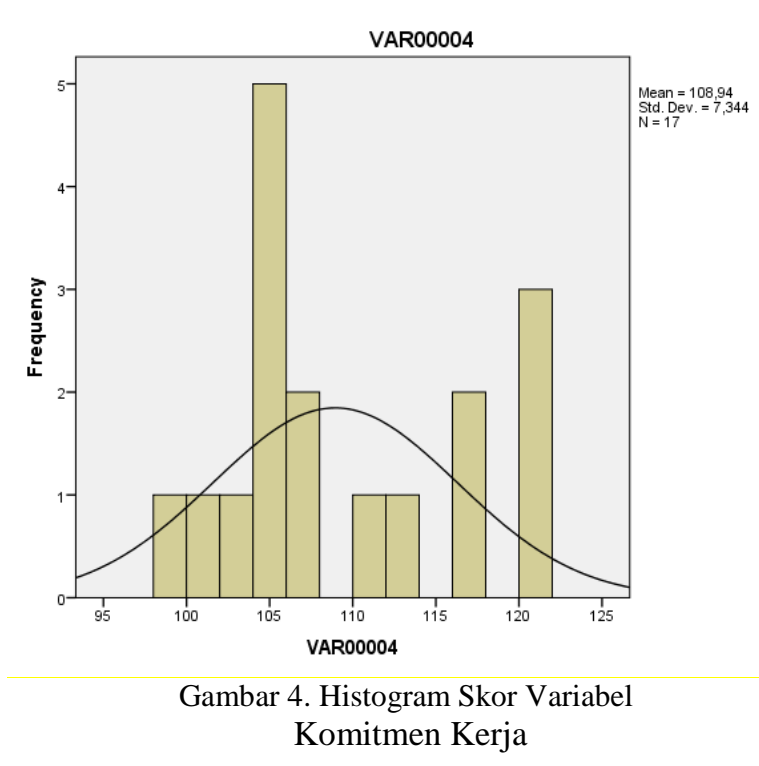

\section{Korelasi Antar Instrumen}

Pada bagian ini merupakan matrik korelasi antara variabel Skor Motivasi Kerja (Y) dengan Budaya
Organisasi $\left(\mathrm{X}_{1}\right)$ diperoleh $\mathrm{r}=0,518$ dengan probabilitas $=0,000<0,05$, maka Ho ditolak, yang berarti bahwa ada hubungan/korelasi yang signifikan antara Skor Budaya Organisasi dengan Motivasi Kerja. Skor Motivasi Kerja (Y) dengan Kepuasan Kerja $\left(\mathrm{X}_{2}\right)$ diperoleh $\mathrm{r}=0,642$ dengan probabilitas $=0,000<0,05$, maka Ho ditolak, yang berarti bahwa ada hubungan/korelasi yang signifikan antara Skor Kepuasan Kerja dengan Motivasi Kerja. Skor Motivasi Kerja (Y) dengan Komitmen Kerja $\left(\mathrm{X}_{3}\right)$ diperoleh $\mathrm{r}=0,729$ dengan probabilitas $=0,000<0,05$, maka Ho ditolak, yang berarti bahwa ada hubungan/korelasi yang signifikan antara Skor Komitmen Kerja dengan Motivasi Kerja.

Tabel 3. Hasil Uji Korelasi Antar Variabel

\begin{tabular}{llrrrr}
\multicolumn{7}{c}{ Correlations } \\
\hline & \multicolumn{1}{c}{ Y } & \multicolumn{1}{c}{ X1 } & \multicolumn{1}{c}{ X2 } & \multicolumn{1}{c}{ X3 } \\
\hline \multirow{3}{*}{ Pearson } & Y & 1,000 &, 518 &, 642 &, 729 \\
Correlation & X1 &, 518 & 1,000 &, 643 &, 604 \\
& X2 &, 642 &, 643 & 1,000 &, 662 \\
& X3 &, 729 &, 604 &, 662 & 1,000 \\
& Y &. &, 016 &, 003 &, 000 \\
Sig. (1-tailed) & X1 &, 016 &. &, 003 &, 005 \\
& X2 &, 003 &, 003 &. &, 002 \\
& X3 &, 000 &, 005 &, 002 &. \\
& Y & 17 & 17 & 17 & 17 \\
N & X1 & 17 & 17 & 17 & 17 \\
& X2 & 17 & 17 & 17 & 17 \\
& X3 & 17 & 17 & 17 & 17 \\
\hline
\end{tabular}

Pada bagian ini merupakan matrik korelasi antara variabel Skor Motivasi Kerja (Y) dengan Budaya Organisasi $\left(\mathrm{X}_{1}\right)$ diperoleh $\mathrm{r}=0,518$ dengan probabilitas $=0,000<0,05$, maka Ho ditolak, yang berarti bahwa ada hubungan/korelasi yang signifikan antara Skor Budaya Organisasi dengan Motivasi Kerja. Skor Motivasi Kerja (Y) dengan Kepuasan Kerja $\left(\mathrm{X}_{2}\right)$ diperoleh $\mathrm{r}=0,642$ dengan probabilitas $=0,000<0,05$, maka Ho ditolak, yang berarti bahwa ada hubungan/korelasi yang signifikan antara Skor Kepuasan Kerja dengan Motivasi Kerja. Skor Motivasi Kerja (Y) dengan Komitmen Kerja $\left(\mathrm{X}_{3}\right)$ diperoleh $\mathrm{r}=0,729$ dengan probabilitas $=0,000<0,05$, maka Ho ditolak, yang berarti bahwa ada hubungan/korelasi yang signifikan antara Skor Komitmen Kerja dengan Motivasi Kerja. 
Tabel 4. Nilai Korelasi $\mathrm{X}_{1}, \mathrm{X}_{2}, \mathrm{X}_{3}$ terhadap Y

Model Summary

\begin{tabular}{rrrrr}
\hline Model & $\mathrm{R}$ & $\begin{array}{c}\mathrm{R} \\
\text { Square }\end{array}$ & $\begin{array}{c}\text { Adjusted } \\
\text { R Square }\end{array}$ & $\begin{array}{c}\text { Std. Error } \\
\text { of the } \\
\text { Estimate }\end{array}$ \\
\hline 1 &, $759^{\mathrm{a}}$ &, 577 &, 479 & 6,843 \\
\hline
\end{tabular}

a. Predictors: (Constant), X3, X1, X2

Tabel 4 menjelaskan besarnya nilai korelasi atau hubungan $(\mathrm{R})$ antara Budaya Organisasi $\left(\mathrm{X}_{1}\right)$, Kepuasan Kerja $\left(\mathrm{X}_{2}\right)$ dan Komitmen Kerja $\left(\mathrm{X}_{3}\right)$ dengan Motivasi Kerja (Y) yaitu sebesar 0,759. Dari output tersebut diperoleh koefisien diterminasi $\left(\mathrm{R}^{2}\right)$ sebesar 0,577 , yang mengandung pengertian bahwa pengaruh variabel bebas $\left(\mathrm{X}_{1}, \mathrm{X}_{2}\right.$, dan $\left.\mathrm{X}_{3}\right)$ terhadap variabel terikat (Motivasi Kerja) adalah sebesar $57,7 \%$.

Tabel 5. Hasil ANOVA

\section{ANOVA $^{\mathrm{a}}$}

\begin{tabular}{crrrrr}
\hline Model & $\begin{array}{c}\text { Sum of } \\
\text { Squares }\end{array}$ & Df & $\begin{array}{c}\text { Mean } \\
\text { Square }\end{array}$ & F & Sig. \\
\hline Regression & 829,293 & 3 & 276,431 & 5,904 &, $009^{\mathrm{b}}$ \\
1 Residual & 608,707 & 13 & 46,824 & \\
Total & 1438,000 & 16 & & \\
\hline
\end{tabular}

Pada tabel 5 di atas untuk menjelaskan apakah ada pengaruh yang nyata (signifikan) variabel Skor Budaya Organisasi $\left(\mathrm{X}_{1}\right)$, Kepuasan $\operatorname{Kerja}\left(\mathrm{X}_{2}\right)$, dan Komitmen Kerja $\left(\mathrm{X}_{3}\right)$ secara simultan (bersamasama) terhadap Motivasi Kerja (Y). Dari tabel di atas terlihat bahwa Fhitung $=5,904$ dengan tingkat signifikansi atau probabilitas 0,009 $<0,05$, maka regresi dapat dipakai untuk memprediksi Motivasi Kerja Guru (Y).

Pada tabel Coefficients, pada kolom B pada Constanta (a) adalah -1,734, Skor Budaya Organisasi $\left(\mathrm{X}_{1}\right)$ adalah 0,021; Kepuasan Kerja $\left(\mathrm{X}_{2}\right)$ adalah 0,389; Komitmen Kerja $\left(\mathrm{X}_{3}\right)$ adalah 0,692. Berdasarkan data di atas, maka dapat dikatakan bahwa: Konstanta sebesar-1,734, koefisien regresi $\mathrm{X}_{1}$ sebesar 0,021, koefisien $\mathrm{X}_{2}$ sebesar 0,389 dan koefisien regresi $X_{3}$ sebesar 0,692.

\section{Uji Reabilitas Masing-Masing Instrumen}

Tabel 6. Hasil Uji Reabilitas Variabel Motivasi Kerja

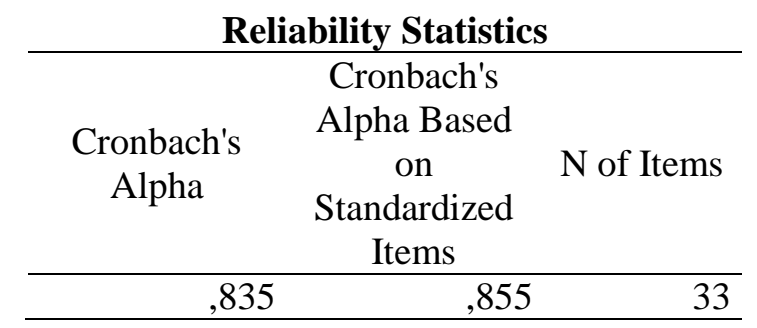

Tabel 7. Hasil Uji Reabilitas Variabel Budaya Organisasi

\section{Reliability Statistics}

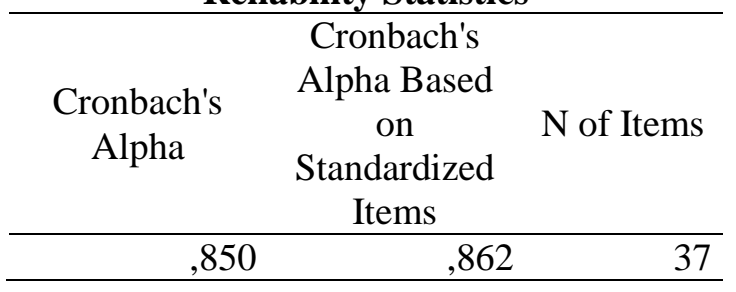

Tabel 8. Hasil Uji Reabilitas Variabel Kepuasan kerja

\begin{tabular}{|c|c|c|}
\hline \multicolumn{3}{|c|}{ Reliability Statistics } \\
\hline & Cronbach's & \\
\hline $\begin{array}{c}\text { Cronbach's } \\
\text { Alpha }\end{array}$ & $\begin{array}{l}\text { Alpha Based } \\
\text { on } \\
\text { Standardized } \\
\text { Items }\end{array}$ & $\mathrm{N}$ of Items \\
\hline ,666 & ,705 & 32 \\
\hline
\end{tabular}

Tabel 9. Hasil Uji Reabilitas Variabel Komitmen kerja

\begin{tabular}{|c|c|c|}
\hline \multicolumn{3}{|c|}{ Reliability Statistics } \\
\hline \multirow{4}{*}{$\begin{array}{l}\text { Cronbach's } \\
\text { Alpha }\end{array}$} & Cronbach's & \\
\hline & Alpha Based & \\
\hline & & $\mathrm{N}$ of Items \\
\hline & $\begin{array}{l}\text { Standardized } \\
\text { Items }\end{array}$ & \\
\hline, 727 &, 785 & 31 \\
\hline
\end{tabular}

\section{KESIMPULAN DAN SARAN}

\section{Kesimpulan}

Dengan menciptakan suasana yang baik terhadap budaya organisasi, kepuasan kerja dan komitmen kerja akan dapat mempengaruhi motivasi kerja guru atau pendidik. Sehingga dengan mengetahui seberapa besar pengaruh budaya organsisasi, kepuasan kerja dan komitmen kerja, maka pihak 
yang berkepentingan dalam hal ini pemerintah dan pengurus yayasan dapat meninjau kembali aspek mana yang perlu ditingkatkan agar kinerja guru atau pendidik termotivasi secara optimal sesuai dengan tujuan organisasi. Motivasi guru akan berdaya guna dan berhasil guna yang diakibatkan dari pengaruh budaya organisasi, kepuasan kerja dan komitmen kerja. Dapat disimpulkan dalam peneltian ini terdapat pengaruh yang signifikan budaya organisasi, kepuasan kerja dan komitmen kerja terhadap motivasi kerja guru.

\section{Saran}

1. Penelitian ini masih memerlukan penelitian lanjutan dan dilaksanakan secara periodik agar data yang didapatkan lebih progresif dan berkesinambungan.

2. Hasil penelitian ini menyimpukan bahwa pentingnya budaya organisasi yang baik, kepuasan kerja serta komitmen kerja guru untuk meningkatkan motivasi kerja di sekolah. Dengan

demikian, perlu penerapan kinerja dan lingkungan yang baik di sekolah.

\section{DAFTAR PUSTAKA}

[1] Steers RM, and Lymann W. Porter. 2003 Motivation and Work Behavior. New York: Mc Graw-Hill.
[2] Robbins, Stephen P.. 1996. Organizational Behavior: Concepts, Controvercies, Applications, New Jersey: Prentice Hall, Inc.

[3] Irawan, Suryani, Sakti. 2000. Manajemen Sumber Daya Manusia. Jakarta: STIA Press.

[4] Hick dan Linkey. 1997. "Adolescen's Social Academic Motivation", Journal: The Education Digest, Vol. 63.

[5] Stephen P., Robbins dan Timothy A. Judge. 2009. Organizational Behavior. New Jersey: Prentice Hall.

[6] Yukl, Gary. 1998. Leadership In Organization, Fourth Edition, New Jersey: Prentice Hall.

[7] Robbins PS. 2002. Perilaku Organisasi, Edisi Kelima. Erlangga, Jakarta.

[8] Allen, N.J and Meyer, PJ. 1997. Commitment in the workplace; theory, Research and Application London, Sage Publication

[9] Bobbi Deporter dan Mike Henaki. 2000. Quantum Bisnis: Membiasakan Berbisnis Secara Etis dan Sehat . Bandung: Kaifa.

[10] Kenneth Stout and Allan Walkee. 1995. Teams, Teamwork \& Team Building The Managers Guide To Team in Organization. Singapore: Prentice Hal.

[11] James W. Walker. 1992. Human Resources Strategy. Singapore: McGraw-Hill, Inc.

[12] John B. Minner, 1992. Industrial Organizational Psycholosi,. New york: Mc. Graw-Hill, Inc.

[13] Panji, Anoraga.. 1998 Psikologi Kerja. Jakarta: Rineka Cipta. 